\title{
LIGHT, SPACE AND AFFLUENT TASTE: ANCIENT POMPEIAN HOUSES AND THEIR DECORATION
}

\author{
S Masters (Stellenbosch University)
}

\begin{abstract}
While Pompeian houses vary in size, ground plan, opulence and specific decorative schemes, they do tend to exemplify certain consistent design motivations. The owner of an urban Pompeian house - or domus - of whatever size, seems to aim towards creating a certain kind of domestic space. This paper investigates some aspects of the design and decoration of Pompeian houses of roughly the $1^{\text {st }}$ century $\mathrm{BC}$ to the $1^{\text {st }}$ century $\mathrm{AD}$, with a particular interest in motives - practical, social, and aspirational - for creating domestic spaces of a particular kind. In doing so three key principles of Pompeian house design and interior decoration will be highlighted: the maximisation of light and space and the display of affluent taste.
\end{abstract}

On 24 and 25 August 79 AD, Vesuvius erupted and the consequences of that famous eruption are well known. The ancient cities on the Bay of Naples in Campania were affected in different ways by the eruption, Herculaneum and Pompeii being completely covered by volcanic fallout debris and pyroclastic flow material. ${ }^{1}$ It has become a cliché to say that despite the human catastrophe Vesuvius in fact did us an immense service by preserving a "snapshot of life" in a medium-sized provincial Roman town of the $1^{\text {st }}$ century AD. While the "snapshot" or "time capsule" metaphors may have worn a little thin, ${ }^{2}$ interest in that particular eruption and the sites of Pompeii and Herculaneum has not waned. The last decade alone has brought forth a flurry of scholarly works, coffee table books, novels and documentaries, and it is said that a film version of Robert Harris' particularly successful novel, Pompeii, is planned for release in $2011 .^{3}$ All these attest to our continued fascination with the catastrophe and the preservation miracle, both provided by Vesuvius.

$1 \quad$ Pliny the Younger's letters (Ep. 6.16 and 6.20) to the historian Tacitus provide an eye-witness account of the $79 \mathrm{AD}$ eruption. Not only do they make fascinating reading but they have also helped palaeo-vulcanologists and ancient historians to reconstruct the likely course of events on those fateful days. Many useful modern summaries of the actual eruption and its effects exist: two recent and readable accounts are Cooley 2003:36-49 and Sigurdsson 2007:50-60.

2 Aldrete 2004:219 for example uses the term "time capsule" in this sense. The "time capsule" or "snapshot" effect plays down the fact that the eruption occurred over two days and thus the cities of Pompeii and Herculaneum were obviously under extreme, abnormal and prolonged duress. The result is that much moveable material would have been disturbed in the chaos that ensued. Scholars such as Allison point out, for example, that finds assemblages are problematic as evidence for patterns of room use, because items had been shifted to varying extents during the state of emergency. She also points out that many houses were undergoing renovation, possibly due to seismic activity that preceded the eruption and warns that "contrary to popular belief, the archaeological record does not represent a town "frozen in time"” (Allison 2007:271).

3 This is according to the Internet Movie Database (http://www.imdb.com/title/tt0958865/ Accessed 30 November 2009). 
While the upkeep and preservation of the cities' ruins prove a logistical nightmare, and despite the mistakes and misconceptions that have arisen out of less than perfect excavation and interpretation of finds in the past, no-one would contest that without that particular eruption of Vesuvius we would know much less about Roman life and culture. ${ }^{4}$ Almost nowhere else are Roman streets, shops, bakeries, hotels, temples, brothels, and baths as well preserved as at Pompeii and Herculaneum. ${ }^{5}$ In addition to these public spaces and buildings, the preservation of entire homes and their contents also sheds light on all manner of things domestic, from what food was about to be served at the next meal, to what possessions the family valued enough to grab in those last terrifying moments. Furthermore, the design and decoration of houses, and the needs and aspirations that drove these processes can give us valuable insight into the lives of the people who lived in them.

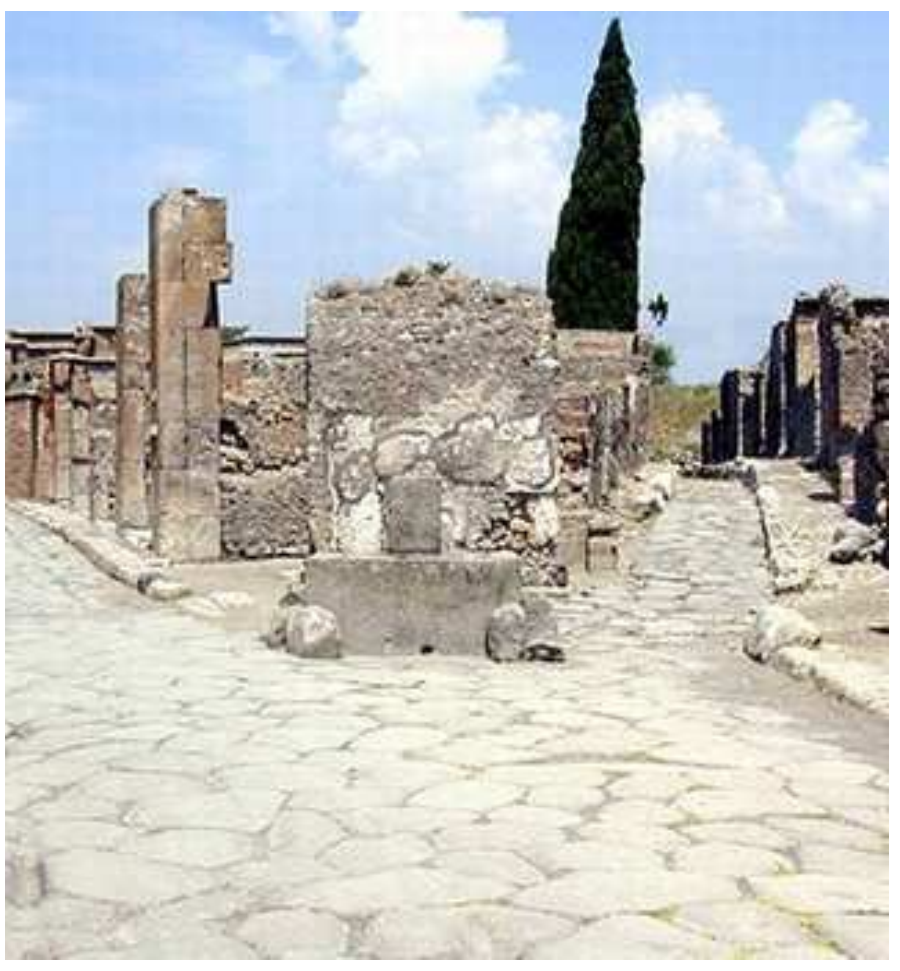

Fig. 1: Via Consolare corner near the Herculaneum gate; Pompeii. ${ }^{6}$

\section{"The Pompeian house"}

Just as there is no one "Italian house" in modern Italy, there is of course no one ancient "Pompeian house" either, though there are typical features that may be

$4 \quad$ Wallace-Hadrill describes the problems, mistakes and misconceptions associated with the site of Pompeii, summing up the state of affairs thus: "It [Pompeii] is at once the most studied and the least understood of sites. Universally familiar, its excavation and scholarship prove a nightmare of omissions and disasters. Each generation discovers with horror the extent to which information has been ignored, neglected, destroyed and left unreported and unpublished" (Wallace-Hadrill 1990:150).

5 While the site of Pompeii was variously occupied by Greeks, Etruscans, Samnites and Romans, the city was deliberately excavated to the level of the 79 AD eruption by Guiseppe Fiorelli and most of his successors. Their approach was to bring the city "back to the appearance it had just prior to its death" (Descoeudres 2007:14) to create the "time capsule" effect referred to earlier. It is only more recently that there have been better attempts to dig and report on the level below 79 AD. Much of this work is still in progress so we still know comparatively little about the pre-Roman city from archaeology. Recent work is reported by Carafa 2007:63-72.

6 http://www.vroma.org/images/mcmanus_images/crossroads.jpg. Accessed 30 November 2009. Credits: Barbara McManus, 2003. 
identified in both cases. Many dwellings of a variety of types, sizes, ground plans and degrees of elegance have been excavated at ancient Pompeii. Furthermore, it is estimated that roughly a third to a quarter of the city is still unexcavated, ${ }^{7}$ so there may be specific ground plans and house types that have not yet come to light. In the Roman world, housing options would have included simple wattle and daub huts, small rustic country villas and multi-story apartment blocks on one end of the scale, and the spacious and opulent seaside villas or country estates on the other. ${ }^{8}$ Somewhere in between was the domus or townhouse (which itself varied in size and ground plan $)^{9}$ and these dwellings are the best represented in the excavations at Pompeii. Scholarly studies have thus tended to focus on the Pompeian domus as the typical Campanian house of the Roman period, and the examples in this paper will mainly be drawn from this store as well. ${ }^{10}$

\section{From High Art to domestic décor}

The exquisite frescos and mosaics discovered in the houses of Pompeii after the Bourbon rulers of Naples and Palermo first began excavating in the early to mid 1700s (Amery \& Curren 2002:32; Foss 2007:28-42) have long enshrined valuable information about techniques, developments of style, and in particular about the richness and originality of Roman art which had often been considered derivative and imitative of Greek prototypes. ${ }^{11}$ However the nature of the study of the works specifically the wall paintings and mosaics - has elevated them to a status they may not have had in their original setting - that of High Art. This is partially explained by the excavation process and the interests of the early excavators and collectors.

7 Laurence 2003:3 quotes the excavated area as "forty four hectares out of the total sixty six hectare site".

8 Not all of these types of accommodation are represented at Pompeii. No multi-story apartment blocks (insulae) have been excavated at Pompeii for example, though they exist at Herculaneum (one example), Ostia and Rome (Wallace-Hadrill 2007:288). The availability and choice of domestic accommodation depended largely on economics, i.e. the occupants' position on the social and / or wealth spectrum. See Wallace-Hadrill 2007 and Ellis 2000 for discussions of several types of Roman housing.

9 Some domūs were however extremely opulent complexes, e.g. the House of the Faun (which occupied an entire city block), the House of Menander and the House of the Vettii. There is also strong evidence for the subdivision of domūs into smaller apartments or units (cenacula), see for example Wallace-Hadrill 2007:288.

10 It is necessary to point out that these houses were typical only of a particular time and place, i.e. Campania of the $3^{\text {rd }}$ century $\mathrm{BC}-1^{\text {st }}$ century $\mathrm{AD}$, and furthermore, that they were typical of the elite classes, rather than the ordinary citizens (Aldrete 2004:226). The excellent location of Pompeii "may have made Pompeii the chosen dwelling place of a disproportionate number of wealthy Romans" continues Aldrete, and therefore housing in the city cannot be taken as representative of the capital nor of the empire in general (op cit).

11 Ling 1991:12-99 reviews the so-called Four Styles of Pompeian Painting, first described and catagorised by August Mau in 1882, but updated, adjusted and still used by subsequent and current scholars. Ling also makes a strong argument for the originality of the Roman wall painters of the era under discussion (see for example 1991:31). 
Pompeii was among the earliest of modern archaeological excavations. Full scale excavations were begun there when early methods of archaeology were hardly scientific, perhaps nothing more than treasure-hunting missions. Crude methods of excavation left much destroyed, misreported or completely unreported before sought after pieces were taken away from the site, many of them ending up in the palaces of Charles III (of Spain, also of Naples) and other private collections (Beard \& Henderson 2001:11; Amery \& Curren 2002:32-47).

Tragically, many wall-paintings and mosaics were hacked from their original locations. One such example is the famous Medea from Herculaneum (Fig. 2), where the section containing a pensive Medea was "squared off" and removed while the remainder of the scene (likely to have contained the children she was about to murder) was not (Beard \& Henderson 2001:31). The original location was left unrecorded.

\section{Fig. 2: Medea from Herculaneum. ${ }^{12}$}

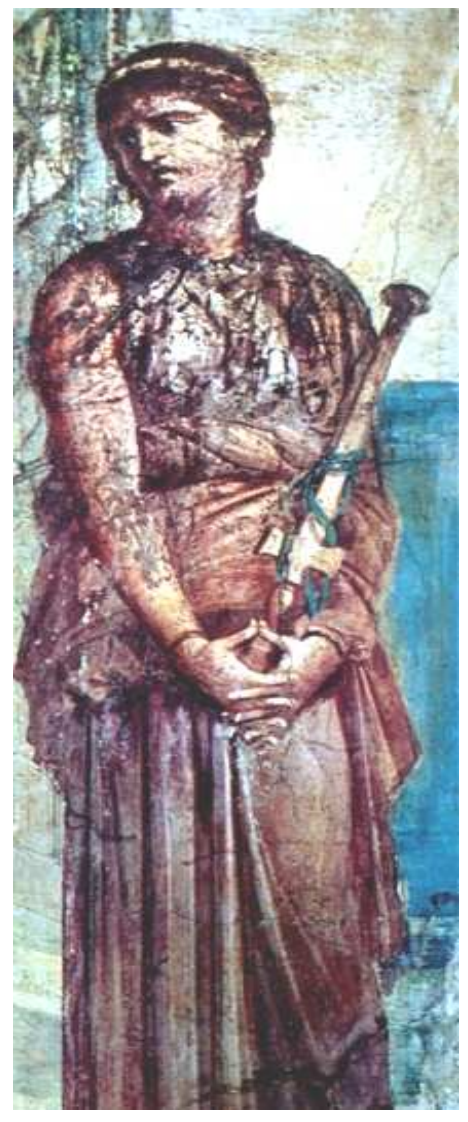

Apart from the tragedy of the physical damage and loss of artefacts during that process is the fact that, dislocated from their original setting, wall paintings and mosaics became studied as objects of High Art, completely devoid of the context of which they were an integral part. ${ }^{13}$ They were viewed in museums or private collections, in sterile isolation from each other and from the domestic spaces that were their canvas. Failure to think of the paintings and mosaics in their original context results in what Beard \& Henderson describe as an impoverished reading of the works (2001:40). Gladly, "holistic" approaches to Pompeian houses by scholars such as Beard (2008), Laurence (2003), Beard \& Henderson (2001), Ellis (2000), Wallace-Hadrill (2007; 1994 and 1990); Ling (1991) and Clarke (1991) to name a few, have redressed this skewed focus. They vehemently argue for "a more contextual approach" to the Pompeian house (Laurence 2003:4), returning the paintings and mosaics to their rightful place — as first and foremost aspects of domestic décor aimed at creating a specific kind of domestic space.

\footnotetext{
12 http://commons.wikimedia.org/wiki/File:Herkulaneischer_Meister_001.jpg.

13 See Beard 2008:147 on this point. Here she does concede that many of the works that were removed and put in museums have survived the ravages of time better than those left in situ.
} 
The domus: a "typical" layout
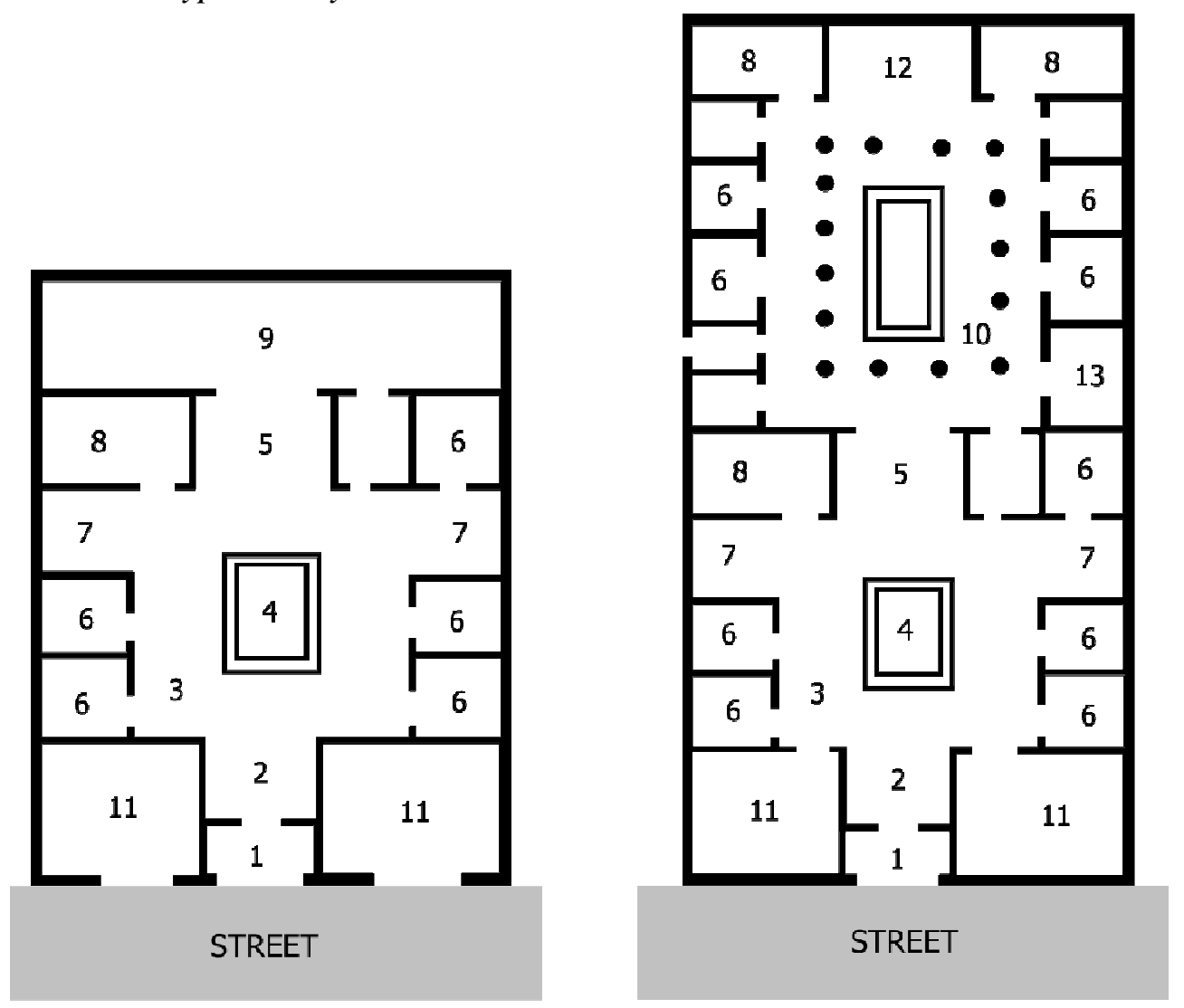

Fig. 3: Hypothetical plan of an atrium domus. ${ }^{14}$

Fig. 4: Hypothetical plan of an atriumperistyle domus.

\section{Key to figures 3-7:}

1. Vestibulum (entrance vestibule)

2. Fauces (passage way)

3. Atrium (central hall)

4. Impluvium (catchment pool)

5. Tablinum ("office")

6. Cubiculum ("bedroom"/ chamber)

7. Ala (alcove / wing)

8. Triclinium (dining room)

9. Hortus (walled garden)

10. Peristylum (colonnaded courtyard)

11. Taberna ("shop")

12. Oecus (summer reception room)

13. Culina (kitchen)

14. Lararium (shrine to the lares)

14 Figures 3-7 have been computer generated by Donovan Jordaan, Stellenbosch University. 
A large number of houses at Pompeii conform to what are termed either an "older" Italic-style atrium house (Fig. 3), or a so-called "Hellenised" atrium-peristyle plan (Fig. 4). ${ }^{15}$ These two (often combined) features of the atrium (no. 3 on the ground plans, basically a central hall) and the peristylum (no. 10, an open-roofed and colonnaded courtyard, often turned into a garden ${ }^{16}$ ) dominate ground plans of many houses excavated at Pompeii. ${ }^{17}$ In such houses, most other rooms, such as the tablinum (no. 5, an "office" / reception room); cubiculae (no. 6, "bedrooms" or chambers); culina (no. 13, kitchen); alae (no. 7, wings / alcoves); triclinia (no. 8, dining rooms); and oecus (no. 12, summer reception / dining room), etc. are arranged around them with what Wallace-Hadrill describes as a "regularity of syntax" (Wallace-Hadrill 2007:282). ${ }^{18}$

\section{Aspects of design: light and space}

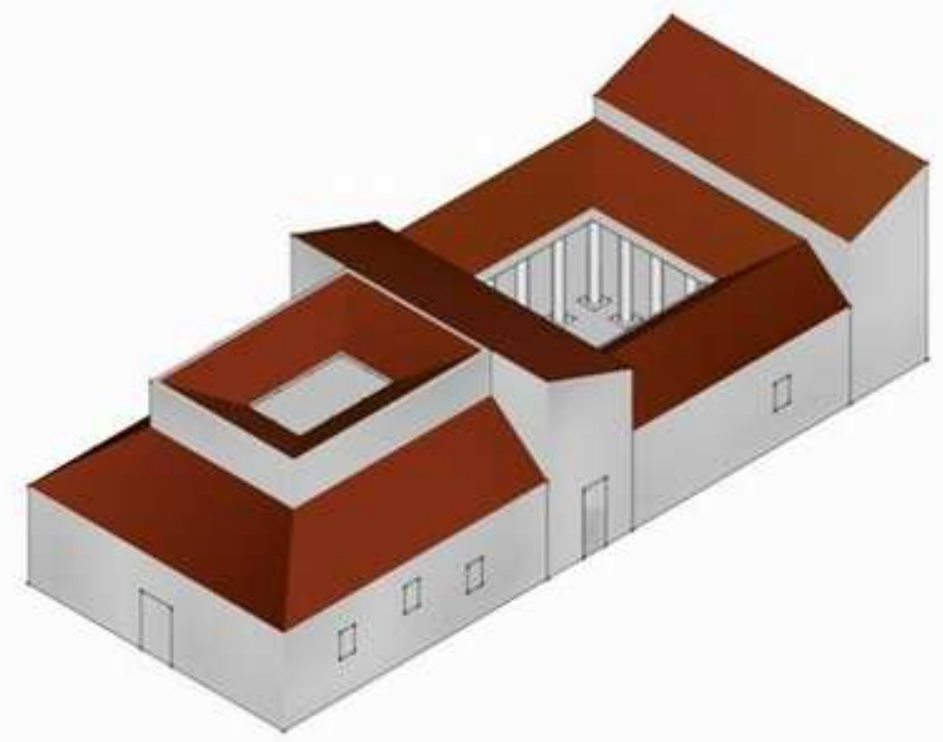

Fig. 5: A 3-dimensional drawing of a typical atrium-peristyle domus.

15 In describing the features of typical Campanian houses, Wallace-Hadrill problematises but does not altogether discard the evolutionary chronologies that are often used to describe the domus (2007:279-291). One of his main arguments is that the "Hellenisation" of the atrium house into an atrium-peristyle plan is perceived too simplistically. His view is that the traditional account of the domus' development does not show "how complex the transformation actually is" (286).

16 Jashemski 2007:487 asserts that "when the Italians added the peristyle to their atrium house they transformed the peristyle by making it a garden instead of leaving it as a beaten clay court or paving it with cobblestones, cement or mosaics, as was done in the Hellenistic house".

17 Depending on wealth and space, houses could feature more than one atrium and peristyle garden. The House of the Faun, for example, has two of each.

18 Many of the terms used by scholars to describe rooms in Roman houses are derived from Vitruvius De Arch. 6 and Varro's Ling. 5.161-2 (Allison 2007:269). Allison points out that while the terminology is useful, and that Pompeians may have used such labels (this is not certain), that the labels and uses of rooms were not fixed, but probably flexible, and usage probably changed over time to accommodate changing needs of the family living in them (2007:270-271). 
The outer façade of the domus gives an impression similar to many modern western townhouses (Clarke 1991:2). The house has high walls, which it typically shares with neighbours (party walls) and is enclosed on all perimeters, as Fig. 5 demonstrates. The street-facing façade features a doorway, which sometimes leads into a small vestibule (vestibulum, no. 1) and then into a narrow passage way called the fauces (no. 2) - literally the "jaws" - which provides passage into the house (Clarke 1991:2). This façade could contain shops and workshops (tabernae, no. 11) which opened onto the street, but all other walls are high and closed, with only a few slit-like windows, often at a high level. The design is, according to our modern sensibilities, highly "private", and it turns its back on the outside world (Ling 1986:309). However, the intention is not necessarily anti-social. We must imagine the noise and chaos of the growing city, the traffic, smells (Pompeii was known for its production of fermented fish sauce, or garum (Amery \& Curren 2002:74)) and the crime - though perhaps not as bad as in Rome. ${ }^{19}$ This urban landscape and its various trappings is what the domus turns its back on and tries to shut out. But a walled-up, small-windowed design could be dark, stuffy, and cramped. And what about views?

One consistent feature of the domus is that it is inward-looking. The Pompeian domus got as much air, light and views as possible centrally, from within. On entering an atrium house the fauces lead directly into the focal point of the domus, the highroofed atrium (no 3). This large central hallway typically had a fair sized rectangular hole in the roof (compluvium) through which rainwater fell and collected in an impluvium (no 4) or catchment pool. The compluvium let in light and air, and prevented the interior from becoming too stuffy, dark and dingy. While not all houses are preserved to roof level, it seems that the design called for higher ceilings in the atrium, aspiring to give a greater sense of height and space (as indicated by the line A-B in Fig. 6). This is surely designed to combat the potential claustrophobia of cramped urban dwelling and contribute to a feeling of airiness in this (front) section of the house.

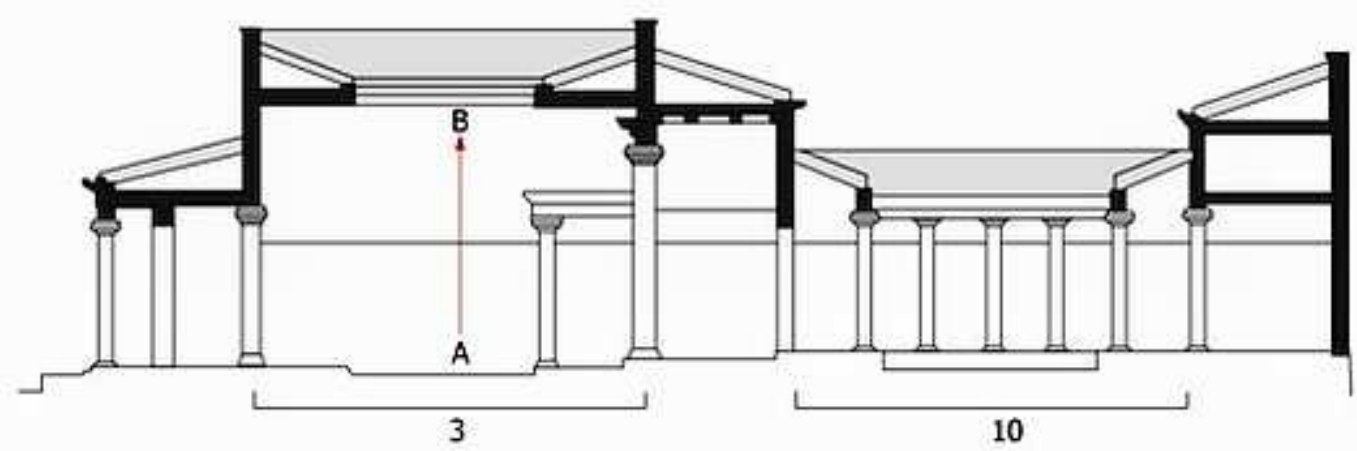

Fig. 6: Elevation of a hypothetical Pompeian domus.

19 The population of Pompeii had not reached the density of that of the capital; this is evidenced by the seeming lack of insulae (flats) in Pompeii. On crime, see Pliny's lament on the appalling number of burglaries in the capital (HN 19.59). 
The second source of air, light and views was the garden, in the form of the hortus, the peristyle garden, or other garden types. ${ }^{20}$ In the peristyle layout, a colonnaded walkway wrapped around an open central courtyard garden, which could be planted with beautifully shaped ornamental shrubs, and was decorated with statuary, garden furniture, mosaics and water features (Ling 1989:323). Rooms opening off the peristyle often had large windows that opened onto the gardens to maximise the access to light and views.

\section{Aspects of design and decoration: An axial plan}

Furthermore, the plan of a typical domus is mainly (though not strictly) axial, i.e. the rooms are laid out along an axis that we can draw from the entrance of the house to its furthermost point (line C-D in Fig. 7). This point could reside either in the hortus (no. 9) in the case of a simple atrium house, or the peristyle garden in the case of an atrium-peristyle plan (no. 10). Many ground plans show a fairly symmetrical arrangement of rooms around the central axis. One such example is the House of the Tragic Poet (Fig. 7). Such symmetria seems to be aspired to, though with a certain amount of flexibility as homes were often renovated, updated, and enlarged subject to constraints of space and other factors.

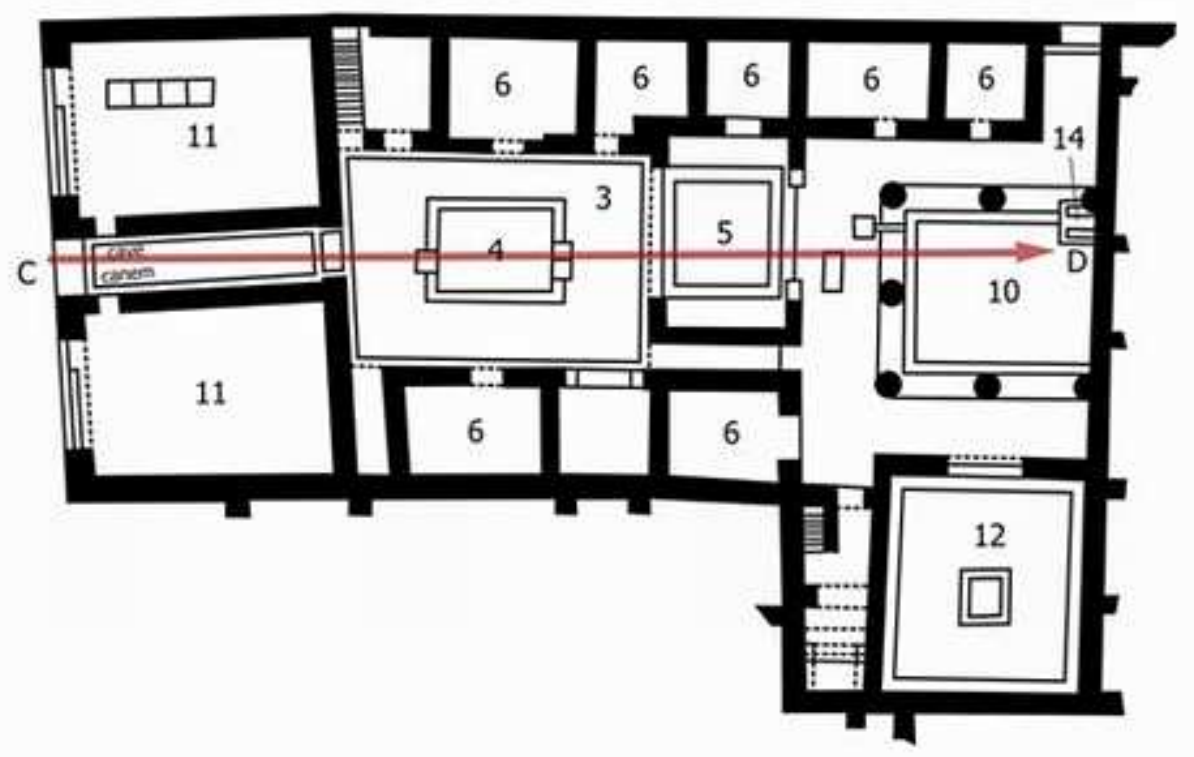

Fig. 7: Ground plan of the House of the Tragic Poet, Pompeii.

20 Jashemski describes how all houses, large and small, aspired to having at least one garden. The owners of smaller houses tried to make place for a garden, even if it was only a small light well with a few plants. Opulent houses would often have several gardens and roof gardens are also known (2007:487). 


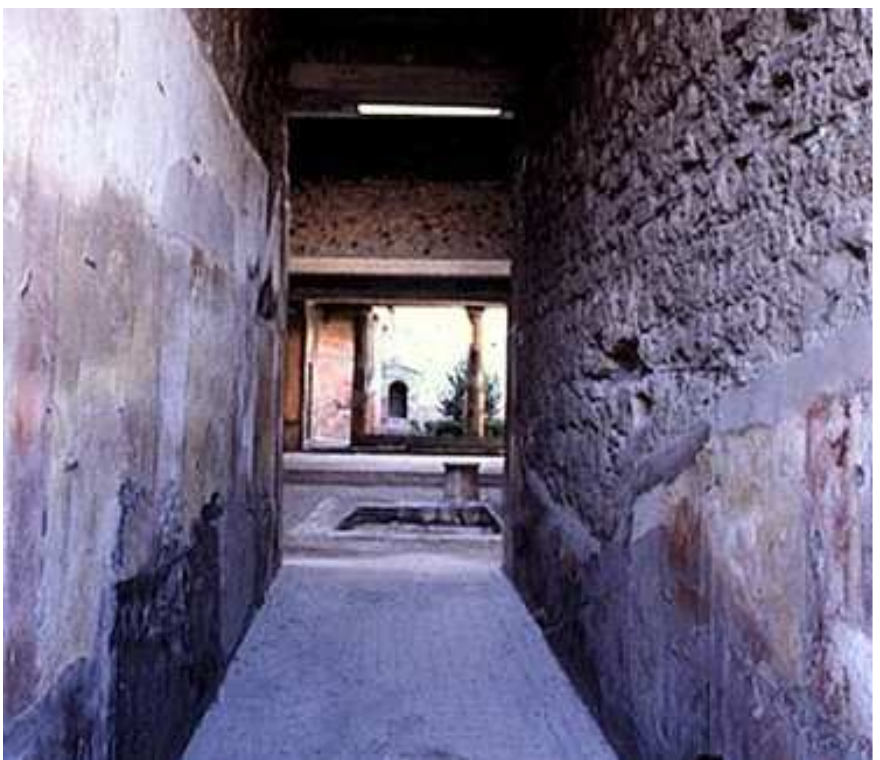

Fig. 8. View from vestibulum to lararium of the House of the Tragic Poet. Pompeii. ${ }^{21}$
What the ground plans do not necessarily make clear is that the architect / designer / owner of the house uses this axis to great advantage by allowing uninterrupted views from the entrance way to the furthermost extent of the house (WallaceHadrill 2007:283; Clarke 1991:2-6). This is achieved through its fairly open plan, i.e. the specific placement or absence of interior walls, doors and windows, allowing such unimpeded views through the house, effectively elongating the space. The lack of a closed boundary between

atrium and tablinum, and tablinum and garden beyond allows a long visual axis through the house (again line C-D in Fig. 7) contributing to the impression of space and spaciousness. In simple terms it creates the illusion that the house is much bigger than it is. The receding planes created by the rooms also create frames through which atrium, tablinum, garden, etc. are successively viewed (Clarke 1991:2-6).

Very often there is a clearly defined focal point to which the eye (and of course the attention) was ultimately directed. The lararium (shrine to the household gods or lares) in the peristyle of the House of the Tragic Poet (Fig. 9) is again a fine example.

Fig. 9: Lararium, House of the Tragic Poet, Pompeii. ${ }^{22}$

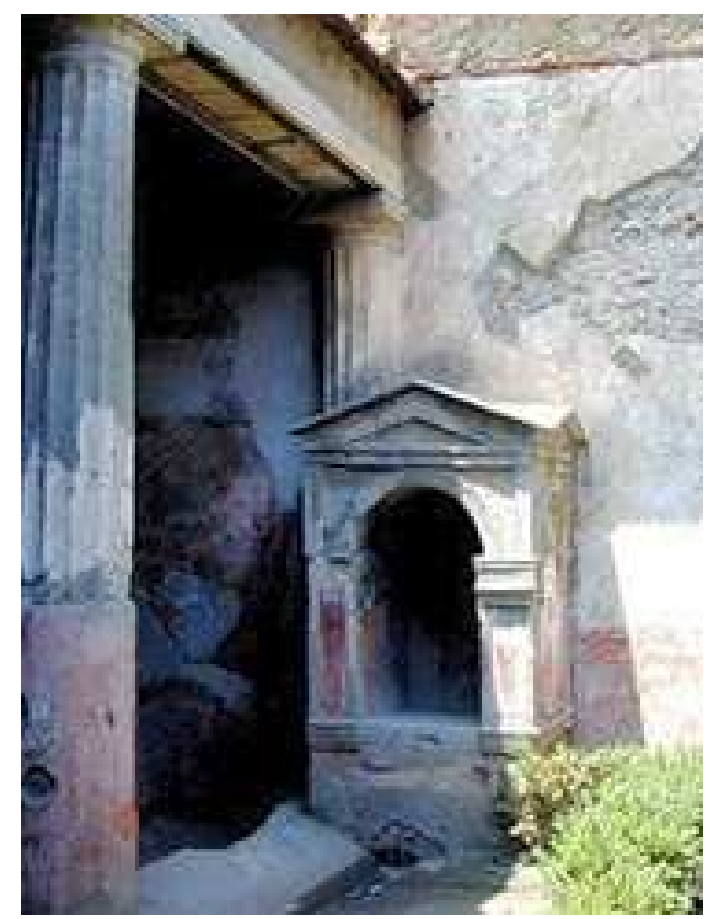

21 http://www.vroma.org/images/mcmanus_images/vestibulum.jpg. Accessed 30 November 2009. Credits: Barbara McManus, 1979.

22 http://www.vroma.org/images/mcmanus_images/tragicpoet_lararium.jpg. Credits: Barbara McManus, 2003. Accessed 30 November 2009. 


\section{Aspects of decoration: How much is enough?}

So far, certain aspects of the architectural codes have been highlighted. The decoration of the house, and its codes, will now be considered. The degree to which the rooms of Pompeian houses were decorated may perhaps seem astounding to us. In the houses of the very wealthy virtually all the walls of all the rooms were brightly frescoed, floors were mosaiced and ceilings stuccoed and painted. ${ }^{23}$ Paint pigments were often brilliant, the most famous being what has become known as "Pompeian red", but other rich pigments - bright greens, yellows, purples, black and white - were used as well (Ling 1991:200-211). With our comparatively conservative tastes of interior design (plain walls, a judiciously chosen and placed painting ...), the overall effect of a Roman house is a bit over the top, garish even.

\section{Aspects of decoration: To what end?}

The question begs to be asked: why decorate to this extent? What does the extent and the type of decoration say about the people who commissioned such works and lived in such a space? What subjects were chosen for depiction? To what end? The answers are not simple but rather related to multiple motivations of the inhabitants of Pompeian houses. One goal is surely to achieve simple aesthetic objectives. Through painting, mosaic, stucco work, plants, rugs, drapery, furniture, statuary and other movable items, the owner could enhance his environment. This much is obvious: a beautiful interior is kind on the eye, and it makes for pleasant living.

However, particularly characteristic of Pompeian houses is the use of decoration not just for aesthetic purposes, but also to create a tromp l'oeil effect, in other words to create the illusion of something that does not exist. To this end, the painters used techniques such as perspective, cast shadows, and chiaroscuro (the modeling of light and shade), to create fictive and alternative realities that could deceive the eye (Ling 1991:23ff). The basic scheme of wall decoration usually consisted of an architectural frame within which other smaller panel paintings (pinakes) or friezes could also be situated, as in Fig. 10. ${ }^{24}$ The subjects of the panel paintings were wide-ranging, from mythological panels, pastoral scenes, cityscapes, harbour scenes, country and seaside villa scenes (the subject of the centrally placed panel in Fig. 10), still lifes, "daily life" scenes, to a variety of garden paintings. The presence and importance of real gardens in the Pompeian home has been mentioned already. Even small gardens must have provided greenery, coolness, views and

\footnotetext{
23 Ling 1991:2 points out that in "fair-sized" houses virtually every room was painted, and even in small houses at least one or two rooms were decorated. Most decorative attention was lavished on the most public rooms (atrium, tablinum, triclinium, oecus, peristylum) while smaller, less visited rooms may have been decorated with simple bands and stripes.

24 The so-called Four Styles of Roman Painting, described by August Mau (1882) are largely defined by their differing treatments of painted architecture, as well as other subjects included in the various schemata. For a recent summary of these Four Styles, see Strocka 2007:302-322. The division into four styles, though artificial, is still considered helpful in many respects.
} 
serenity in the home and, therefore, in daily life. ${ }^{25}$ The Pompeians also delighted in creating beautiful fictive gardens through tromp l'oeil painting, incorporating plants, flowers, fruit, birds and other creatures as well as architectural features such as bird baths, fences, pergodas and fountains.

Fig. 10: Wall painting (in the Third Style) containing a panel painting of seaside villas, from the House of Lucretius Fronto, Pompeii. ${ }^{26}$

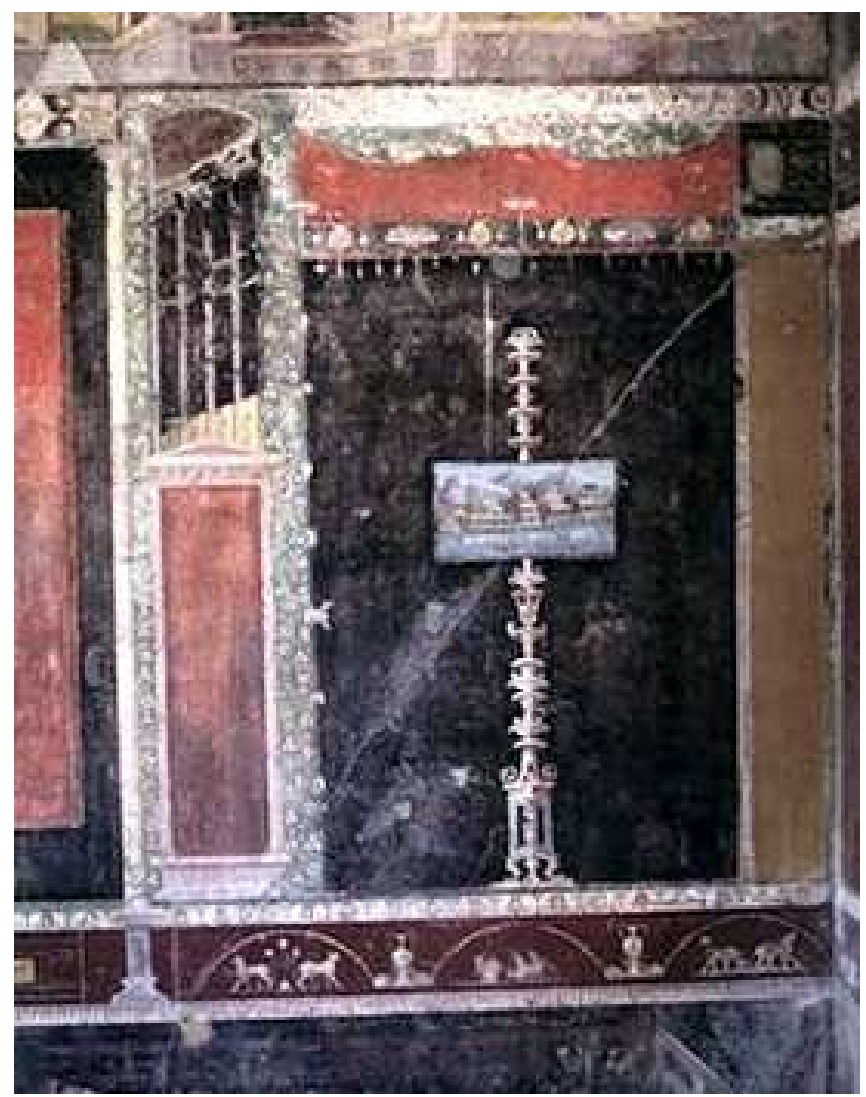

The treatment of the painted architectural content is also illuminating. In some cases architectural features dominate the wall: hypothetical masonry, columns, friezes and cornices are replicated and through the techniques mentioned above, receding and projecting architectural forms give the impression of depth on a flat wall (Ling 1991:23ff; 1986:315-316). ${ }^{27}$ Sometimes "windows" are opened, in which views onto an outside world are painted through illusionistic painting. In this case, one goal of the painted decoration is clearly to enhance the architectural programme of the house. Painted architecture can be employed to maximise space by creating an illusion of depth, particularly in small poky rooms, of which there are numerous examples. $^{28}$

In other cases, entire architectural (and other) vistas are painted on the wall, as though there is no wall at all. In this way the inhabitants of the domus are allowed a look through the wall onto an outside world - and another reality.

25 Jashemski 2007:487-498 discusses the centrality of various kinds of gardens to the lives of the Romans as well as the importance of the garden in the design and development of the house. See her older but comprehensive works $(1993 ; 1979)$ for intricate details of individual gardens from Pompeii, Herculaneum and villas in the vicinity.

26 http://www.vroma.org/images/mcmanus_images/paula_chabot/house/pchouse.36.jpg.

Accessed 30 November 2009. Credits: Paula Chabot, 1993.

27 The impression of depth on the wall is particularly typical of Second and Fourth Style Pompeian painting.

28 One good example is Bedroom 46, The House of the Labyrinth, Pompeii. 
Though not of a domus, bedroom M from the Villa of P. Fannius Synistor at Boscoreale (Fig. 11) is a good example. ${ }^{29}$ This painted vista "opens up" the wall completely, further enhancing the spatial effects, but the interest in an alternative reality to that which actually exists outside is clear. The exquisite garden paintings from Primaporta are another excellent example of the spatial transformation of a small cramped room "into an open-sided pavilion set in a magic forest" (Ling 1986:316).

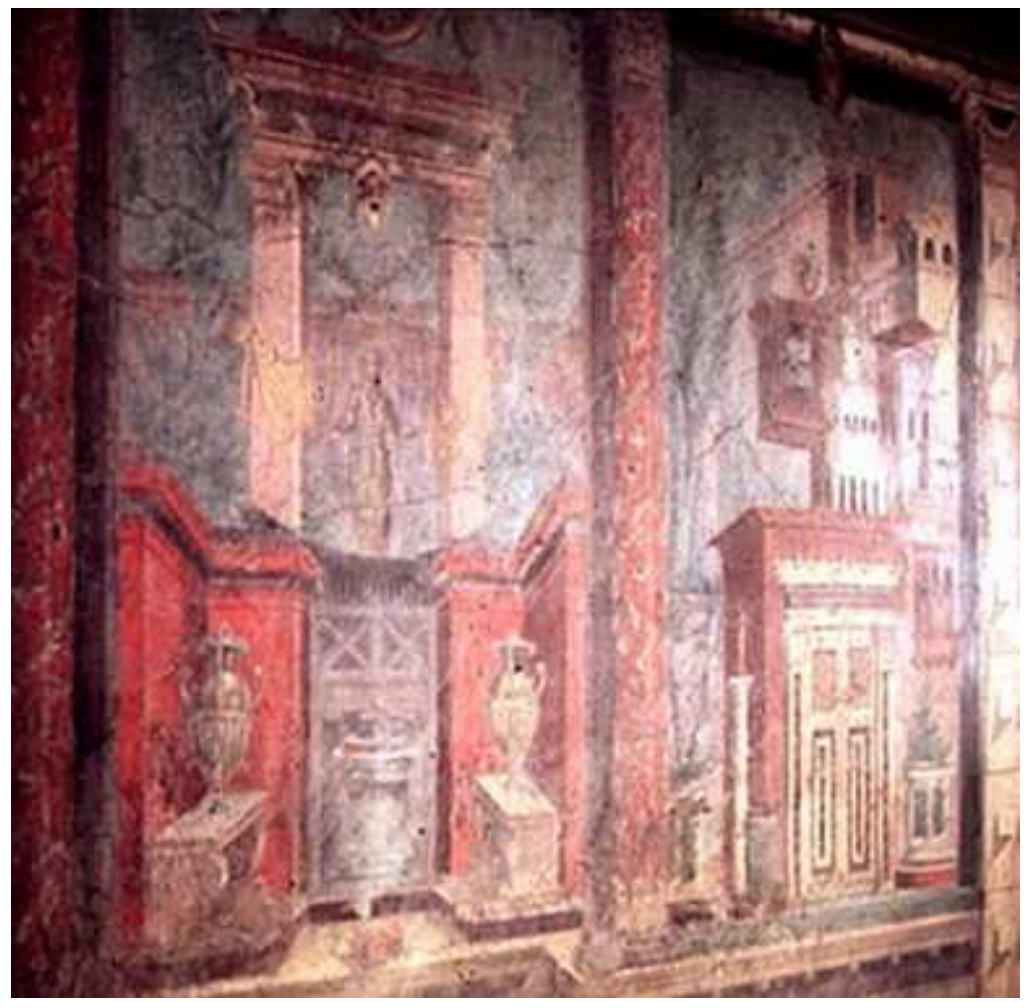

Fig. 11: Detail of an architectural wall painting from cubiculum $M$ from the Villa of P. Fannius Synistor, Boscoreale. ${ }^{30}$

In creating views that are beautiful, idyllic, peaceful, and tranquil there is surely an intention to present a contrast to what really lurks beyond the wall: the busy street, the humdrum world. This kind of painting creates for the occupants of the home an alternative reality. The panel paintings may be intended to transform the walls into "picture galleries" or pinacothecae (Ling 1991:135), but they may also be perceived as (ambiguously) presenting vistas from alternative realities, or as windows onto them. However, alternative reality in Pompeian painting at times seems to verge on hyperreality. Illusory painting is taken one step further in presenting a reality that not only does not actually exist, but could not possibly exist.

\footnotetext{
29 Recreated in New York, at the Metropolitan Museum of Art (Rogers Fund 1903: 03.14.13).

30 http://www.vroma.org/images/mcmanus_images/boscoreale.jpg. Accessed 30 November 2009. Credits: Barbara McManus, 1980.
} 
In creating architecture that is insubstantial and completely nonsensical, wall painting seems to fulfill an escapist function. Vitruvius is scathing of this kind of painting when he describes the following:

Now there are monstrosities painted on stuccoed walls rather than true to life images based on actual things - instead of gables there are ribbed appendages with curled leaves and volutes. Candelabra are seen supporting figures of small shrines, and above the gables of these, many tender stalks with volutes grow up from their roots and have, without it making any sense whatsoever, little seated figures upon them. Not only that, but there are slender stalks which have little half-figures, some with human heads and some with beasts' heads (Vitruvius, De Arch. 7.5.4, trans. Pollitt).

Though Vitruvius does not approve, here we see that (for some owners of houses and painters at least) there was a strong interest in recreating a make-believe world, where architecture is fictive, rather than realistic, and human and non-human creatures can mingle in the same tableau. There is perhaps a similar blurring of the boundaries and sense of hyperreality in the well known frieze from the oecus in the Villa of the Mysteries. In this large mythological frieze that occupies four walls of the room, satyrs, the god Bacchus, strange demi-gods or demons and humans all seem to plausibly occupy the same world. Such decoration is playful, can be humorous and is possibly escapist to the extreme. ${ }^{31}$

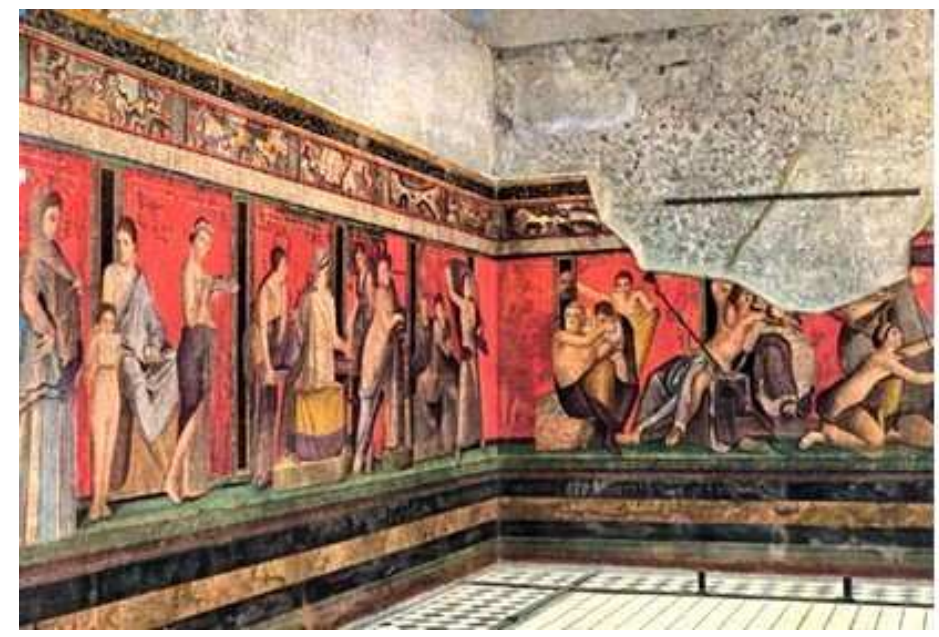

Fig. 12 Oecus from Villa of the Mysteries, Pompeii. ${ }^{32}$

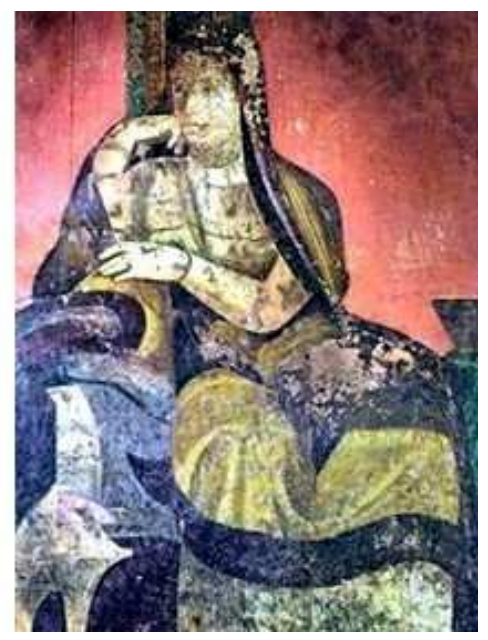

Fig. 13: Domina? Detail from oecus. ${ }^{33}$

\footnotetext{
31 This is not to deny the serious religious functions the frieze may have had. It is likely that the images are operating on various registers, simultaneously.

32 http://www.accla.org/actaaccla/ramage6.html. Accessed 30 November 2009.

33 http://www.accla.org/images/ramage8.jpg. Accessed 30 November 2009.
} 


\section{Aspects of decoration: personal propaganda}

The example of the oecus in the Villa of the Mysteries may also support another important motivation in Pompeian domestic decoration: self-promotion. It has been suggested that the domina of the house was possibly an initiate or priestess of the cult of Bacchus (Kerényi 1996:355). This is plausible, though difficult to prove. If this is the case, however, it is easy to read the commissioning of a mythological frieze of this nature (perhaps even featuring her in it, Fig. 13) as an act of personal propaganda, an advertisement of her religious status and social importance. To understand these decorative needs further, we ought to think beyond aesthetics and look to those commissioning paintings for their homes, and also their audience.

The owners and occupants of Pompeian domūs require a more complex discussion than there is space for here. However, it is generally agreed that for the familia — the paterfamilias in particular — the house was not simply a domestic space but also a mechanism for social display (Beard 2008:100-103; Wallace-Hadrill 1994:4). And it may be that this was so especially among the rising commercial classes (the nouveaux riches) of the $1^{\text {st }}$ century $\mathrm{AD}$, who consciously used décor as one means to assert their claims to social ascendancy. ${ }^{34}$ The memorable though fictional Trimalchio in Petronius' Satyricon is often offered as a portrait of this nouveau riche "type" - newly moneyed, lacking in taste, and climbing the social ladder. ${ }^{35}$ The house could become a vehicle of social advancement precisely because it was not, despite its closed-off, inward-looking appearance, "private" (Hales 2003:1-2; Clarke 1991:1-2), or not at least in the modern sense of the word. In addition to the fact that wealthy Pompeians shared the house not just with family members but with various types of attendants, servants and slaves (Beard 2008:99), Pompeian houses were not secluded personal spaces, off limits to the outside world. Our own notion of privacy means that we tend to think of Pompeian houses in the same way as our own, as opposite to public life. Clarke describes the house as "the locus of the owner's social, political and business activities, open both to invited and uninvited visitors" (Clarke 1991:1-2). In this way the house was not private (though some sections were more private than others) nor completely public, but rather it should be described as the interface between the public and the private.

$34 \quad$ Ling says that: “... wall-painting was socially necessary. Any householder with aspirations to a degree of respectability felt obliged to commission murals in at least the most important rooms of his house; and the social advancement of freedmen and the small commercial classes during the early Imperial period meant that there were more and more people with such aspirations" (1991:220).

35 Trimalchio's over-the-top and ostentatious display of wealth can be seen at various points in the text, not least of all in the descriptions of the physical structure and decoration of his house. This portrait is surely intended to represent an extreme case of "tastelessness". While there are obvious dangers of reading Petronius' satirical portrait of Trimalchio (and of Roman life) too literally, as Beard points out (2008:85), there are houses at Pompeii that may present a similar case of "nouveau riche pretensions going wrong" (Beard 2008:112). She gives the example of the House of Octavius Quartio at Pompeii, pointing out that archaeologists disagree whether this house would have been considered "tasteless" in its own time. She suspects it would have been (Beard 2008:111-113). 
Civic life entered the domus in the form of daily visits by business associates, political allies, and also clientela. According to Clarke, one of the key design principles of the domus was to enable and streamline the process of receiving such guests at the daily ritual called the salutatio (visit by dependants), which took place in the tablinum (Clarke 1991:4). ${ }^{36}$ Clarke describes how the fauces-atrium-tablinum axis of the house directed the clients in the direction of their patron to the following effect: "A client emerging from the tunnel-like confines of the fauces directly faced the goal of his or her visit, the paterfamilas, standing or seated at the end of the axis in the tablinum and dressed in the toga" (Clarke 1991:4). Surely not all visits to the patron were infused with such high drama; however the point that the physical properties of the house accommodated and directed visitors through the house in a certain way is a valid one.

Another important social occasion that might be described as a "ritual" was the cena (dinner party). Respectable Romans did not frequent the taverns or fast food places, but dined at home, often with invited friends, associates and political allies (Hales 2003:2). The cena also presented occasions for the display of good taste and social standing; again the example of Trimalchio's cena, though satirical, offers some evidence of the opportunity for social propaganda through décor and personal effects. In both of the "rituals" of salutatio and cena, house design and décor framed the experience. ${ }^{37}$ The architecture and decorative effects work together to direct the members of the household or visitors into the house, and their ultimate destination, and in short, impress them with the opulence, intricacy, skill, cleverness or playfulness of the design. To this end, the socially important areas such as the entrance vestibulum and fauces, atrium, tablinum, triclinia, oeci and peristyles usually received the finest colour, most complex design and most detailed and interesting mythological paintings or mosaics (Dunbabin 1999:306-307; Ling 1991:2).

A point remains to be made about the content of many wall paintings and mosaics in Pompeian houses. A large number of prominently situated paintings had mythological themes, and very often these paintings used Greek stories (such as those known from the epics of Homer) or were direct copies of famous Greek works (Ling 1991:128-135). ${ }^{38}$ Why this particular interest? While Rome's reception of Greekness is highly complex, it has been generally observed that in Pompeii, Greek objects and Greek culture were (still) considered by many to be a sign of good breeding and affluent taste. ${ }^{39}$ Another likely interest in mythological paintings is in their

36 Beard questions whether the process of salutatio was actually as "grand and formal" as scholars (following Vitruvius) have suggested, especially in Pompeii, which is, relative to Rome, a small town (Beard 2008:103). However, even if the process was not such a formal one, the space does seem well set up to accommodate it, and the house does reveal certain patterns of logic of arrangement around domestic rituals.

37 Clarke 1991:6-12 also discusses several more formal religious rituals — the sacra privata that took place in the home, showing how the physical space was significant in framing ritual experiences in general.

38 Paintings with mythological themes were often placed in the atrium, tablinum, triclinia and oeci, the rooms previously noted as rooms for general display.

39 Cohen's discussion of the Alexander Mosaic points out that though the reception of Greeks and their cultural products was complicated and controversial for many reasons, the moral outrage 
availability as exempla, moral paradigms, presenting an opportunity for reflection and learning (Bergmann 1994:226). The use of exempla is well-attested in literature as a characteristic of the Roman mindset, and the content of much domestic décor of Pompeian domūs can be seen to fulfill this goal. ${ }^{40}$ Interior decoration presents continuous and fluid opportunities for reflection, discussion and learning in the context of the home and the activities that take place in it. This, it seems, is one of the specific goals of the Pompeian house.

In summary, the choices that are made in the design and decoration of the Pompeian house are many. One motivation is practical, related to optimizing space and light, making the house seem bigger, brighter and better than it actually is. Another is social and, probably, political; it is likely that houses, being more public than private, were expressions of social as well as political aspirations. The upmarket Pompeians updated and enhanced their décor as they tried very hard to display their affluent taste, keep up with the proverbial "Joneses" and climb the social and political ladder. A further explanation for the proliferation of decoration and design is informed by the layout of the house, and specifically, the contrast we find between its interior and the urban world outside. The city outside presented the stark reality of urban life: hustle, bustle, heat, crowded, noisy and smelly streets. Inside the house, however, one is transported to an exquisite fictive reality, one where imaginary architecture opens vistas onto another world, birds perch on birdbaths inside bedroom walls and the great epics of Homer are proclaimed in the reception halls and dining rooms. This reality is kinder on the eye and on the mind. It is through the interrelating interior surfaces - walls, floors, ceilings and furnishings - that the Pompeian householder can achieve his goals to distract, impress, enrapture and even educate the viewer, whether that be himself, his family, clients, political allies, or if the unlikely opportunity arose, the emperor himself.

\section{BIBLIOGRAPHY}

Aldrete, G S 2004. Daily life in the Roman city. Rome, Pompeii, and Ostia. Westport, Connecticut \& London: Greenwood.

Allison, P M 2007. Domestic spaces and activities. In Dobbins \& Foss 2007:269278.

Amery, C \& Curren, B 2002. The lost world of Pompeii. London: Frances Lincoln.

Beard, M \& Henderson, J 2001. Classical art: From Greece to Rome. Oxford: Oxford University Press.

Beard, M 2008. The fires of Vesuvius: Pompeii lost and found. Cambridge, Mass.: Belknap Press of Harvard University Press.

did not seem to extend as far as Pompeii and other Campanian towns where Greek works of art were considered items of "cultural prestige" (1997:185-186).

40 See Bergmann's detailed discussion of the programme of decoration in the House of the Tragic Poet, a house rich in mythological paintings. She traces various routes through the house and describes the process of moving through it as "reading" the decorated house (Bergmann 1994:225ff). 
Bergmann, B 1994. The Roman house as memory theatre: The House of the Tragic Poet in Pompeii. The Art Bulletin, 76.2:225-256.

Clarke, J R 1991. The houses of Roman Italy, 100 BC-AD 250. Ritual, space and decoration. Berkley \& Los Angeles: University of California Press.

Cohen, A 1997. The Alexander mosaic: Stories of victory and defeat. Cambridge: Cambridge University Press.

Cooley, A E 2003. Pompeii. London: Duckworth.

Descoeudres, J-P 2007. History and historical sources. In Dobbins \& Foss 2007:9-27.

Dobbins, J J \& Foss, P W (eds.) 2007. The world of Pompeii. London \& New York: Routledge.

Dunbabin, K M D 1999. Mosaics of the Greek and Roman world. Cambridge: Cambridge University Press.

Ellis, S P 2000. Roman housing. London: Duckworth.

Hales, S 2003. The Roman house and social identity. Cambridge: Cambridge University Press.

Harris, R 2003. Pompeii. New York: Random House.

Foss, P W 2007. Rediscovery and resurrection. In Dobbins \& Foss 2007:28-42.

Jashemski, W 2007. Gardens. In Dobbins \& Foss 2007:487-498.

Jashemski, W 1993. The gardens of Pompeii, Herculaneum and the villas destroyed by Vesuvius, Appendices. New Rochelle: NY: Caratzas.

Jashemski, W 1979. The gardens of Pompeii, Herculaneum and the villas destroyed by Vesuvius, Volume 1. New Rochelle: NY: Caratzas.

Kerényi, K 1996. Dionysos: Archtypical image of indestructible life. Princeton: Princeton University Press.

Laurence, R 2003. Roman Pompeii. Space and society. London \& New York: Routledge.

Mau, A 1882. Geschichte der decorativen Wandmalerei in Pompeji. Berlin: G. Reimer Verlag.

Pollitt, J J (trans) 1983. On fresco wall painting. Vitruvius VII, 5, 1-7. In The art of Rome c. 753 B.C. - A.D. 337: Sources and documents. Cambridge: Cambridge University Press.

Sigurdsson, H 2007. The environmental and geomorphological context of the volcano. In Dobbins \& Foss 2007:43-62.

Strocka, V M 2007. Domestic decoration: Painting and the "Four Styles". In Dobbins \& Foss 2007:302-322.

Wallace-Hadrill, A 2007. The development of the Campanian house. In Dobbins \& Foss 2007:279-291.

Wallace-Hadrill, A 1994. Houses and society in Pompeii and Herculaneum. Princeton: Princeton University Press. 